\title{
RUSSIAN VECTOR IN SERBIAN POLITICS: IMPACTS AND OUTCOMES ON REGIONAL RELATIONS 2
}

https://doi.org/10.18485/iipe_balkans_rssc.2020.ch13

Abstract: The thesis of Russian malignant influence has been one of the key factors of the homogenization of the EU foreign policy since 2014. Although it has been declared that full EU membership is Serbia's strategic goal, in this period, we are detecting Belgrade's intensive collaboration with Russia. The number of bilateral meetings has been increased, the number of interstate agreements has multiplied, military cooperation intensified, and public opinion towards Russia is more positive than negative (which can be seen in the results of opinion polls). Serbia is striving for the EU, but its foreign policy is not at all in line with the proclaimed foreign policy goals of the EU and other key European countries (Germany, France, the UK). To some extent, it can even be stated that Serbia remains the last 'island of Russophilia' west of the border of Belarus. The question is: why? This article first analyzes the historical and political reasons for strengthening Russian influence in Serbia, as well as Serbia's interests to work more closely with Russia, regardless of the EU. Then, the 'character of the Russian vector' on Serbian politics will be examined - its political, economic, and military dimension. The third part of the paper seeks to answer the question: how will it affect regional relations? The fourth part is the concluding considerations.

Keywords: Serbia, Russia, Russian Influence, Russian vector, regional security, the Balkans.

\footnotetext{
${ }^{1}$ Research Fellow, Institute of International Politics and Economics, Belgrade, Serbia. E-mail: dusan@diplomacy.bg.ac.rs.

${ }^{2}$ The paper presents findings of a study developed as a part of the research project "Serbia and challenges in international relations in 2020", financed by the Ministry of Education, Science, and Technological Development of the Republic of Serbia, and conducted by Institute of International Politics and Economics, Belgrade.
} 


\section{INTRODUCTION: ‘SERBS AND RUSSIANS - BROTHERS FOREVER!'}

In the center of Belgrade, one can buy a T-shirt with the inscription: 'Serbs and Russians - brothers forever!' (In Serbian: Срби и Руси - браћа заувек!; In Russian: Сербы и Русские братья навсегда!) In Serbian pop culture, just one similar slogan can be found: Montenegro and Serbia - it is one family! However, relations between the Serbs and Montenegro are specific in everything. They relate to family relations, metanastastasic movements and centuries-old common history, which includes belonging to not only one church but also to one culture, and are therefore unmatched by any other bilateral relationship (Cvijić, 1922, pp. 88-110). Also, a phenomenon in itself is that this story of the 'brotherhood of Serbs and Russians' is manifested in the years when a huge 'anti-Russian propaganda' is being carried out (Kjeza, 2016). Except for Belarus, the Donbas and Lugansk, something similar is undetectable west of the Russian border. Even in countries like Bulgaria, which not only had better relations with Russia throughout history than Serbia but who also owed to Russia and the Russians their liberation from Turkish occupation.

Moreover, relations between the Serbs and the Russians, which go beyond interstate relations, concern both church relations and cultural influences, and are historical in nature, long and rich, but it cannot be said that they were good at all stages (Jovanović, 2012, pp. 89-91). Simply, the Serbs and the Russians were not 'always' brothers! In some periods, after the Russo - Turkish War of 1875-1878, these relations were even dramatically poor. Because of support for the formation of Greater Bulgaria, Serbian King Milan Obrenovic turned completely to Austro-Hungary; after the October Revolution, a river of Belogardians led by General Piotr Wrangel poured into Serbia, King Alexander led a fierce anti-communist policy, and the Kingdom of Yugoslavia would remain the last European state to establish bilateral relations with the Soviet Union (in June 1940) (Radojević, 2014, pp. 46-61). Finally, the critical phase in Yugoslav-Soviet relations was in 1948 when, following the Informbureau resolution, Yugoslavia was virtually ousted from the 'Eastern Alliance'. Bad relations between Belgrade and Moscow would continue until May 1955, when the President of the USSR Council of Ministers Nikita Khrushchev visited Belgrade (Dimić, 1998, pp. 23-56). Certainly, from 1918 until the early 1990s, it is impossible to speak of 'pure' Serbo-Russian relations, since Serbia and Russia were parts of larger integrative entities - Yugoslavia and the Soviet Union. However, this does not affect the conclusion reached about periods of deterioration of the 
relationship. And therefore, it does not affect the hypothesis that the message 'Serbs and Russians - brothers forever!' is a new discourse in the popular culture and political public of Serbia. Pro-western authors rarely miss the opportunity to emphasize that this is based primarily on mythology, more than on real historical facts, often blaming 'Russian propaganda' or 'Russian hybrid warfare' for such results (Abrahamyan, 2015).

As in other European countries, the spread of Russophobia is encouraged by stories of 'propaganda' and 'hybrid warfare'. Yet, in Serbia, such attempts fail completely (unlike in the rest of Europe), so instead of Russophobia, we have evident growth in the Russophile population. This makes one think that neither 'propaganda' nor 'hybrid warfare' is responsible for this, because if it were, then the Russians would have achieved greater and better results in some other countries. Looking from the essential point of view, but also from a statistical point of view, it is impossible that one comprehensive Moscow activity (both 'propaganda' and 'hybrid warfare' are even more complex operations) produces a concrete and positive result in only one case. In Serbia!

The data from the opinion poll (last presented in September 2019) seem almost unbelievable, showing that $39.9 \%$ of respondents rate Serbia-Russia relations with the highest possible score 5 , while $38.3 \%$ rate these bilateral relations with 4 . So, almost $80 \%$ of respondents have a positive attitude towards relations with Russia (Institute for European Affairs, 2019, p. 5). When asked: is Russia a friend or an enemy? - $87 \%$ answered - a friend, $11 \%$ - I do not know, and only 2\% - an enemy (Institute for European Affairs, 2019 , p. 9). Paradoxically, the majority of respondents $(25.5 \%)$ consider Russia as Serbia's largest donor, while the EU is second (25.3\%), and China is third $(18.9 \%)$. Although they are among the largest donors of various development and social programs, this is not the perception of Serbian citizens of Germany (6\%), the USA (1.8\%), Japan (1.3\%) and Norway $(0.6 \%)$ (Institute for European Affairs, 2019, p. 10). According to the data of the Statistical Office of the Republic of Serbia, Russia is not among the top 15 donors. Economic cooperation between the two countries, although growing, remains modest. So, Serbia exports twice as much to Bosnia and Herzegovina than to Russia, while the total investment of Russian companies in Serbia is still less than of Austrian companies.

It should be noted that Vladimir Putin is by far the most popular politician in the Serbian public, more than any domestic politician. And in his honor, the residents of Adzinci (part of the Gornji Gaitan, Medvedja municipality), decided to officially change the name of their place to Putinovo 
(in November 2018). 'The residents of Banstol, near Indjija, named the Temple of the Blessed Mary dedicated to the Serb victims of the wars of the 1990s and modeled after the Russian churches, the Putin's Church' (Popularan u Srbiji: Putin ima selo, crkvu, rakiju, 2019). The Russians and Putin would have won the elections in Belgrade more convincingly than in Moscow.

Naturally, there is no government or any political structure in Serbia that can ignore this public mood. Anyone who tries to build their politics on the anti-Russian narrative would be marginalized. The project of presenting 'Russian malignant influence' as political and even wider - social danger, generously funded by the EU and NATO, has simply failed in Serbia. For the Serbs, Russia is part of the solution, not part of the problem in political calculations. Why? There are three reasons for a noticeable rise in Russia's popularity among the Serbs.

First, Serbia was bombed by NATO only two decades ago (1999). The consequences of the aggression are not only the material destruction and killings of the people but also political ones: the US initiated a project to create an 'independent Kosovo', which violated Serbia's territorial integrity but also damaged the dignity of the Serbs (Proroković, 2018). A large number of political and propaganda activities that took place both during the period of preparation and implementation of military aggression (19981999) and during political preparations for the 'declaration of an independent Kosovo' were based on pure lies and fabricated images.

Possibly, these images served the United States to receive the necessary support for the 'Kosovo project' in its public. But in the long run, this way they have closed the door to the opportunities of growth of not only American but of Western influence in general in the wider Serbian political public (Proroković, 2012, pp. 121-179). Therefore, despite officially proclaimed Western integration policies, which include Serbia's EU membership but also military neutrality, Serbia's attitude towards the Western alliances is relatively unfavorable (the EU's popularity stagnates or declines slightly, while the relation towards NATO remains negative).

In the latest survey of youth (between 15 and 30 years of age) conducted during August 2019, it is noticeable that more respondents oppose EU membership than support it (for 38\%, against $40 \%$ ), and as many as $56 \%$ think that 'living in Serbia would be the same or worse if it became an EU member'. According to $33 \%$ of respondents, in its foreign policy appearance, Serbia should rely more on Russia, while at the same time, 21\% think the EU is the most important ally (Više mladih Srba protiv ulaska u EU, a za savezništvo sa Rusijom, 2019). 
Secondly, the success of Russia, the gradual stabilization of the situation in this country, as well as its increasing role in international relations, have not gone unnoticed. To the extent that it could, Russia has protected Serbia's interests during the last Yugoslav wars (1992-2000). It was one of the guaranteeing powers for the peace solution in Bosnia and Herzegovina (the Dayton Agreement), as well as a permanent member of the UN Security Council, which supported the adoption of Resolution 1244, proposing a completely new solution to the 'future status' of Kosovo within the Republic of Serbia and respecting the principles of international law (Proroković, 2012, pp. 440-448). Unlike the western powers gathered in NATO, Russia had a completely different view on the dissolution of Yugoslavia, escalation of the war in Kosovo, the proclamation of 'independent Kosovo', as well as on several other questions concerning regional security (the last in the series, at the time of writing this article, was the adoption of a controversial law in Montenegro that practically legalized the seizure of property of the Serbian Orthodox Church, which Moscow condemned and demanded this to be resolved by new negotiations between state institutions and the Church).

In Serbia, Russia is anticipated as a 'patron', in terms of politics, historical image, collective confidence and individual dignity, which is why there is such a positive mood and spread of Russophilia. The escalation of the Ukrainian crisis and the conflict in EU/NATO-Russia relations only confirmed this belief with the Serbs, because it forced them to decide, and given the relatively weak or average EU rating and the catastrophic rating of NATO, the determination was most often made only in one way. The diplomatic, political or military successes of Russia (Syria, the east of Ukraine, even the referendum in Crimea, construction of the Turkish flow) have only reinforced this commitment.

And thirdly, it is certainly the 'Putin factor'. This is somewhat a global phenomenon, despite the campaign conducted by all key Western media against it, the President of Russia has been recognized and acknowledged as one of the most important politicians of the modern world (Vlahović, 2014). In Serbia, this is manifested in the assertion that he is not one of the most important but the most important politician of the modern world, and Russophilia is often manifested or explained as a 'belief in Putin's political moves'. Combined with the first and especially the second reason, this has an effect and is reflected in the growing popularity of Russia. Hence the slogan: 'Serbs and Russians - brothers forever!' 


\section{RUSSIAN-SERBIAN STRATEGIC PARTNERSHIP: ENERGY, TRADE, POLITICS, ARMS}

To some extent, it can even be stated that Serbia remains the last 'island of Russophilia' west of the Belarus border. Does this benefit Russia's foreign policy in Serbia? Undoubtedly - yes! Russia's interest in Serbia has increased since the summer of 2006. It is a period of intense talks on the 'future status of Kosovo' co-ordinated by Marti Ahtisaari, the UN Secretary-General's special envoy (Proroković, 2013, pp. 148-156). Although Ahtisaari's work continued until 2007, and later his role was assumed by the 'Troika', in 2006, it essentially became clear what the proposal of the 'Western partners' would be. It also became clear that they did not provide support for this either in political circles in Belgrade nor in Moscow (All polls showed that most citizens would certainly be against the solution from the Ahtisaari plan, but when it comes to the work of the West in the Balkans there are many examples of avoiding the referendum and ignoring the majority opinion or manipulating their will; and when it comes to the Ahtisaari process, all they needed was the signature of a Serbian official and the decision of one of the competent institutions for it to be applied, the opinion of citizens did not interest them at all.).

Simply, the Ahtisaari Plan meant that Serbia would 'accept Kosovo's independence' with which Belgrade did not agree, and Moscow supported Belgrade in this. It is still unclear, and it is less relevant for the conclusions of this paper to which extent was Vladimir Putin's 'hard line' on the 'Kosovo issue' shaped by the 'lobbying of Belgrade' and to which extent by Russia's strategic goals and geopolitics (Interestingly, until 2006, within the Contact Group, Russia represented a 'constructive partner' thus giving legitimacy to all proposals made by 'Western partners' including the famous Conclusion from 2005 that 'future status of Kosovo' must be based on 'three $\mathrm{NO}^{\prime}$ : no to return to the state before 1999; no to the accession of Kosovo to some other state; no to division of Kosovo). It is only since 2006 that Russia's relationship with Serbia has entered a whole new phase, based on Moscow's 'Kosovo policy'. Russia is explicitly opposed to any kind of 'Kosovo Albanians independence' and firmly defends the legal framework defined by UNSC R1244 (paradoxically, but at times Russia did this tougher than representatives of Serbia). The evidence of change in Russia's attitude is also a change in the route of the South Stream strategic pipeline.

According to the first version, the pipeline was meant to stretch across the territories of Russia, Bulgaria and Romania to Hungary. But, by summer 2007, when a 'big energy agreement' supposed to be signed between the two 
states, the route has been changed. Romania has fallen out of the game, and Serbia became a key partner in this business, next to Bulgaria (Proroković, 2015, pp. 11-23). Part of the 'energy agreement' was the privatization of Serbia's state-owned oil company by Gazprom which ended successfully, enabling Gazprom to survive on the European market after 2014 (thanks to Serbia's free trade agreement with the EU), despite a number of political pressures and attempts to reduce the company's influence in the EU.

Also, after long negotiations in January 2013, an interstate agreement on Russian loan for the reconstruction and development of the 800 million dollar railway infrastructure was signed (Ruski kredit za železnicu, 2013). Therefore, in addition to the energy sector, Russia became a guarantee of the development of another area, which was important not only for the economy but also for Serbia's safety. At the beginning of 2019, the successful realization of this work initiated the signing of a new loan agreement worth 172.5 million euros for the construction of a unified dispatching center for train traffic management in the territory of all Serbia. This loan provided 'financing of $75 \%$ of work' while the remaining $25 \%$ was provided by the government of Serbia from the budget funds. Significance for the Russian side is reflected in 'encouragement of exports of goods and services' (Božić Krainčanić, 2019).

In May 2013, Belgrade and Moscow signed the document with the pretentious name 'Declaration of Strategic Partnership between Serbia and Russia'. The document states that the strategic relations 'include all spheres of cooperation, including politics, trade, economy, culture, technic and education' (Deklaracija strateškog partnerstva Srbije i Rusije, 2013, p. 2). Still, even after this, the two biggest contracts between the two countries remained those related to energy and railway infrastructure. The scope of foreign trade exchange fluctuated from 2.3 to 3.3 billion euros for the past six years, with the share of oil and oil derivatives in Russian exports to Serbia at $36 \%$, gas $27 \%$, and about $20 \%$ import of other necessities (products and services) related to the energy sector. When it comes to Serbian exports, apples make $9 \%$, cheese $2 \%$, strawberries $2 \%$ (all three products are among the top ten), and the share of the other agricultural products is about $10 \%$.

Undoubtedly, after the turbulent 'years of sanctions' (2015-2017), when there was a partial devaluation of Russian ruble and 'big economic shock' in Russia, trade relations are stabilized and the volume of exchanges is growing, which is encouraging, but the structure of import/export is such that it cannot be satisfactory. On the Russian side, the largest share is made of energy, i.e., raw materials, and on the Serbian side of agricultural products. 
Table 1: Foreign trade exchange in goods between Serbia and Russia (2013-2018)

\begin{tabular}{|c|c|c|c|c|c|c|}
\hline & 2013 & 2014 & 2015 & 2016 & 2017 & 2018 \\
\hline Export & $1.062,7$ & $1.029,3$ & 724,8 & 795,12 & 995,1 & $1.023,6$ \\
\hline Import & $1.903,5$ & $2.235,1$ & $1.746,2$ & $1.503,4$ & $1.586,0$ & $2.037,1$ \\
\hline Trade & $2.966,2$ & $3.364,2$ & $2.471,0$ & $2.298,5$ & $2.581,1$ & $3.060,7$ \\
\hline
\end{tabular}

Source: Chamber of Commerce and Industry of Serbia, 2019, p. 2.

Unlike commercial relations, which have stagnated, political relations have experienced two large uplifts: first, during the already described period 2006 - 2007 and second, after 2014. Escalation of the Ukrainian crisis has influenced the EU and NATO to thoroughly change their relationship with Russia, which included establishing the regime of (partial) sanctions and submitting numerous initiatives in different international organizations in order to politically condemn Russia. Never, on any occasion, in any international forum, have representatives of Serbia voted against Russia. In fact, Serbia is the only European country that has not followed any recommendation of the EU and/or NATO and has not introduced any sanctions to Russia (nor against individuals, nor institutions). On the other side, Russia has always and everywhere supported Serbia regarding the 'Kosovo issue' as well as on other issues (for example, in July 2015, Russia has put a veto on British motion for resolution on 'Srebrenica genocide' that stipulated one interpretation of events in the civil war in Bosnia and Herzegovina). The role of Russia in the process of withdrawal of recognition of the so-called state of Kosovo also remains 'hazy'. The first country that has withdrawn the recognition of Kosovo was Suriname, but 'Namely, when that note was sent to our (UN) mission in New York, Suriname's foreign minister was visiting Moscow', said Djukic, who in the past served as Serbia's ambassador abroad (Did Suriname's Kosovo decision go via Moscow?, 2017).

Even more visible is the sudden takeoff in intensified and expanding military cooperation. Russia has so far helped (direct aircraft donations and armored patrol vehicles, favorable terms of purchase or credit) by equipping Serbian armed forces with six MiG-29 planes, thirty armored patrol and reconnaissance vehicles (BRDM-2MS) and thirty tanks (T-72 MS). 'Serbia has already purchased four new, Russian helicopters Mi-35M, and three transport helicopters Mi-17' (Ikodinović, 2019), as well as one anti-aircraft 
system 'Pancir S-1' (which serves to defend from low-flying objectives and because of its tactical and technical characteristics is currently the best tool for defense from such attacks). The curiosity is also the fact that Russia's sophisticated anti-aviation system S-400 only once in history has been transferred to another country's territory because of a joint military exercise: in Serbia in October 2019.

In a strange way, in a resolution dedicated to 'ensuring territorial integrity and sovereignty' from December 2007, which effectively represented the 'political response' of the Serbian National Assembly on the Ahtisaari Plan, the concept of 'military neutrality of Serbia' was established. The topic virtually was not formally talked about until 2018 (although politicians in their public appearances liked to repeat it) when the process of writing new strategies of the Republic of Serbia started: national security and defense strategies. Since 2019, when these documents were adopted, military neutrality has become formalized: 'Development of the partnership cooperation of the Republic of Serbia with NATO, based on the policy of military neutrality through the Partnership for Peace and the monitoring position in the Collective Security Treaty Organization (ODKB) contributes to the stability of the Republic of Serbia. For further development of democracy, stability and prosperity of the region, for the Republic of Serbia, it is important to improve relations with the US, Russia, China, and other traditional partners and major factors of the international community' (Narodna skupština Republike Srbije, 2019, p. 6).

Through tighter military cooperation, Russia is actually keen to ensure Serbia's military neutrality, which at this point in Moscow is seen as a noentry into NATO. Russian Major General Sergey Lipovoy says, 'Serbia is a Moscow ally in the Balkans and a neutral state, which is why it needs constant protection, especially since it is surrounded by air bases of NATO. Russian and Serbian military cooperation is quite productive. /.../ Serbia is not in the alliance, and that status requires permanent protection, especially since Serbia is literally surrounded by NATO bases in Romania, Hungary, Italy, Bosnia, and Bulgaria. Furthermore, let us not forget the Kosovo separatists who regularly perform provocations against the Serbs and the accession of neighboring Montenegro to NATO' (Ruski general: Srbija je pod ruskom zaštitom, 2019). Looking at the size and quality of military cooperation, this trend has not been seen in Serbian-Russian relations since the beginning of XIX century (The First Serbian uprising) and somewhat in the period just before the outbreak of the Balkan wars in the XX century (First and Second Balkan War). 


\section{RUSSIAN VECTOR: IMPACTS AND OUTCOMES ON REGIONAL RELATIONS}

However, despite the excellent and fruitful cooperation between Serbia and Russia in the areas of energy, railway infrastructure, political and military relations, there is somewhat unclear what the Balkan vector of Russian policy implies. To talk about 'equal bilateral relations', given the power of actors (Serbia and Russia), their historical role and position in the ongoing international relations - is not realistic. Nor is it realistic that Russia 'separately projects' its foreign policy activities through some sort of 'special policy' towards one partner of the size and power of Serbia. Also, it is unrealistic that Russia would sacrifice some other, broader interests, for the sake of its relations with Serbia. The documents of The Conception of Russia's Foreign Policy, from 2013 and 2015 (in Russ. Концепция Внешней политики Российской Федерациии) have no mention that the Balkan Peninsula is in any way in Russia's foreign policy focus. However, at the same time, it does not mean that the Balkan is a 'distant periphery'. Ever since 2013, it is noticeable that the main goal of this country is to be one of the poles in the emerging multipolar system. 'State policy in the field of national security and socio-economic development of the Russian Federation contributes to the realisation of strategic national priorities and effective protection of national interests. Currently, a stable basis has been created for further dissemination of the economic, political, military and spiritual potential of the Russian Federation, and to increase its role in the formation of the multipolar World' (Koncepciya vneshney politiki Rossiyskoy Federatsii, 2016, point 7).

As a result, Russia 'will work to anticipate events and lead them', and in this sense, in point 4, it is said that the aim is to occupy the 'strong and authoritative position in the international community, as it best corresponds to the interests of the Russian Federation as one of the influential and competitive centers of the modern world' (Koncepciya vneshney politiki Rossiyskoy Federatsii, 2013, point 2). At the same time, it also noted that 'maximising the potential of the North Atlantic Alliance (NATO) and empowering its global function is carried out in contradiction with international law, by intensifying military activities of the bloc's countries, further expanding the alliance and approximating its military infrastructure to the Russian borders, which poses a threat to national security' (Koncepciya vneshney politiki Rossiyskoy Federatsii, 2016, point 15). 'Hence the fierce reaction of the official Moscow even after the announcement that little Montenegro will join this military alliance' (Proroković, 2018, p. 601). 
Russia is conducting its bilateral relations with Serbia in a line of its strategies, which are politically and contextually totally acceptable to the Serbian public. Thus, indirectly, it affects the political elite, still well oriented towards the EU and even NATO (see, for example, IPAP agreement between Serbia and NATO). For Russia, it is primarily important to prevent or slow down further NATO expansion and to create a solid basis for further transmission of 'economic, political, military and spiritual potential'. Serbia can play both roles. First, the Serbian population that inhabits Montenegro, Bosnia and Herzegovina and other countries in the region can be a solid dam to strengthen NATO's influence in the Balkans. In Bosnia and Herzegovina, due to the existence of the Republic of Srpska, the Serbs are even in a position to formally block the accession of the country into this military alliance, while in Montenegro due to the strong opposition from the population, the referendum was not organized (NATO membership was declared in the Assembly, where from 81 MPs 46 voted, and according to public opinion pools $54 \%-66 \%$ of citizens were explicitly against it.). Despite official claims that 'everything went smoothly' (the mission was carried out - Montenegro joined NATO!), thanks to this resistance, a strong 'anti-NATO lobby' was created in Montenegro even before the state formally joined this military alliance. Just how polarized society in Montenegro is, is best shown by mass demonstrations against the authorities' decision to try to take a portion of the Serbian Orthodox Church's property that began in December 2019. Accordingly, it can easily happen for Montenegro to be the first state to leave NATO!?

NATO is the reason for Moscow's initiative to intensify military cooperation with Serbia as well as the reason for maintaining excellent political relations, which often are not followed by the increasing trade exchanges and expanding economic cooperation. By investing in military cooperation, Russia is essentially helping to maintain Serbia's military neutrality project, which guarantees that Serbia will become a dam for the expansion of NATO interests in the Balkans and by improving cooperation on various political issues, the existing status is maintained. And this status does not permit the arrangement of regional geopolitical order in accordance with the concept of the United States (with the support of other European stakeholders, primarily of Great Britain and Germany).

It is noticeable that such an approach is conducive to Serbian geopolitical interests. The ongoing spatial distribution of power and influence in the region is linked to agreements accepted by Serbia: the Dayton Agreement (1995), Resolution 1244, as well as the invocation of norms of international 
law (human rights and freedoms, religious freedoms) that can be guaranteed (issue of the Serbian Orthodox Church in the territory of its canonical jurisdiction). By abandoning these legal frameworks, Serbia risks making its geopolitical position dramatically worse (Proroković, 2012, pp. 719-758). NATO initiatives (or more precisely, the United States initiatives, which then engage the entire NATO in realizing their interests in the Balkans) and the EU, which sought to change the Dayton Agreement, repeal Resolution 1244 and worsen the status of the Serb population in some former Yugoslavian republics, are issues of geopolitical importance, and this is another reason why resistance in the Serbian society was created and articulated not only against NATO (or the USA) but also against the EU. Russian support, stemming from the compatibility of views on key issues, was welcomed in Serbia (primarily in intellectual circles and in the political public), thus opening the door to both expanding Russian influence in Serbia and strengthening the Russian vector in regional frameworks.

Map 1: Map of Eparchies of Serbian Orthodox Church (including Orthodox Ohrid Archbishopric)

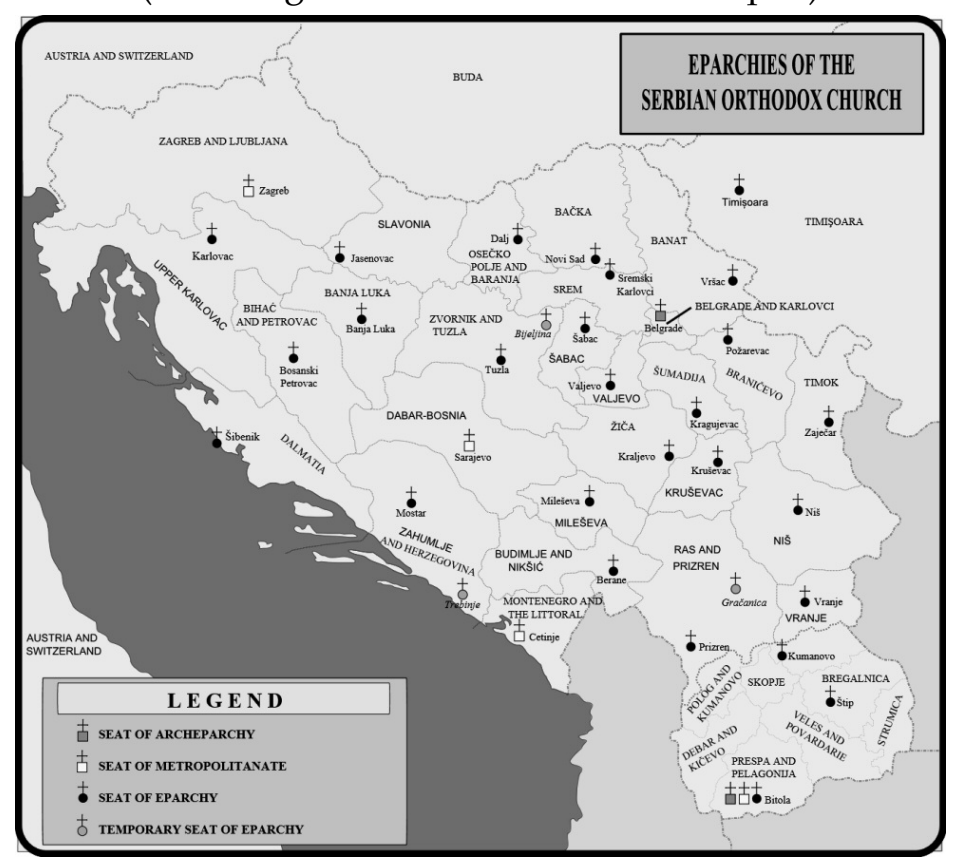

Source: Internet 
Relying on the support of the Serbian public, intellectuals, as well as individual institutions (primarily the Serbian Orthodox Church), intensifying political and military cooperation, but also promoting some projects of regional importance in the field of energy (the Turkish Stream pipeline), Russia has over the years created a solid basis for spreading its impulses throughout the Balkan region. Of course, this approach has many disadvantages, first of all, it is reflected in the pronounced antagonization in the region, in which every 'playing on the Serbian card' automatically produces a counter-effect on the other side (among Albanians, for example). However, it should also be emphasized that in designing a new 'Balkan policy', Russia did not have much choice since all other Balkan nations were already in NATO or on the way to joining NATO.

\section{CONCLUSION}

Historically, Serbian - Russian relations have generally been good. For several periods, these relations were entering a problematic phase, but in general - the Serbs and the Russians never made war against each other, nor did their actions affect the other party. Since 2006, we have been attending a new phase of strengthening and expanding these relationships. Serbia has found a powerful ally in Russia, who can protect it against the US and leading EU states in an attempt to completely derogate from Resolution 1244, to make a fundamental change to the Dayton Agreement that would lose the Republic of Srpska an equal status (thus, the Serbs in $\mathrm{BiH}$ would lose guaranteed privileges) and in resolving a number of other things (primarily identity issues, but also creating one 'correct historical image' of the causes and consequences of the Yugoslav civil war for the West). The intention of the 'political West' is to finally establish a new geopolitical order in the Balkans, in which the Serbian corpus will be fragmented, divided into several states, and also shattered by the construction of new hybrid identities (the construction of a Montenegrin identity on the anti-Serbian agenda, which has no basis in the history, for example).

For Russia, on the other hand, Serbia and the Serbs practically represent the 'only choice' in the entire Balkans in an attempt to achieve a strategic goal: stopping further NATO expansion. Russian influence, which strengthens Serbian resistance, is certainly affecting regional relations currently most visible in Montenegro and Bosnia and Herzegovina, and to a lesser extent in North Macedonia. The interesting thing is certainly the fact that, unlike Western structures that pursue their interests through the 
control of elites, Russian structures have paid more attention to influencing some traditional centers of power (the church and its close organizations) and the public in the broadest possible sense. Thus, a workaround has put pressure on the political structures of the Republic of Serbia, which, despite a declarative commitment to EU membership and good relations with NATO, have since 2014 avoided following the EU and NATO decisions against Russia.

For now, we have results, especially if we compare the current situation to 2006. At that time, there was almost no Russian influence in the Balkans, except in the energy sector and culture, and Serbia was facing a complete 'geopolitical collapse'. Everything is different today. And this has consequences not only for Serbia's foreign policy but for regional relations as a whole. Russia has 'returned' to the Balkans. Serbia helped her with this. Serbia has begun a phase of 'geopolitical consolidation'. Russia helped her with this.

\section{REFERENCES}

Abrahamyan, E. (2015). Pax Russica in the Balkans: Serbia Between Myth and Reality. E-International Relations, pp. 1-8. Retrieved from https://www.e-ir.info/2015/04/30/ pax-russica-in-the-balkans-serbiabetween-myth-and-reality/. Accessed 25 December 2018.

Božić Krainčanić, S. (2019, November 12). Šta sve (ne)znamo o ruskim železničkim kreditima? [What do we (not) know about Russian railway credits?]. Radio Slobodna Evropa, retrieved from https:// www.slobodna evropa.org/a/srbija-rusija-novi-kredit-zeleznica/30266320.html. Accessed 1 January 2020.

Chamber of Commerce and Industry of Serbia. (2019). Spoljnotrgovinska razmena Republike Srbije i Ruske Federacije [Foreign trade of the Republic of Serbia and the Russian Federation]. Chamber of Commerce and Industry of Serbia, Belgrade.

Cvijić, J. (1922). Balkansko poluostroo [The Balkanian Peninsula]. Belgrade, Državna štamparija Kraljevine SHS.

Deklaracija strateškog partnerstva Srbije i Rusije [Declaration on strategic partnership between the Russian Federation and the Republic of Serbia]. (2013, April 24). Retrieved from http://ambasadarusije.rs/data/ uploads/Deklaracija_1.pdf. Accessed 1 January 2020. 
Did Suriname's Kosovo decision go via Moscow? (2017, November 2), retrieved from https://www.b92.net/eng/news/politics.php?yyyy= 2017\&mm=11\&dd=02\&nav_id=102703. Accessed 11 January 2020.

Dimić, Lj. (1998). Josip Broz, Nikita Sergejevič Hruščov i mađarsko pitanje 1955-1956 [Josip Broz, Nikita Khrushchev and Hungarian issue 19551956], Tokovi istorije [History flows], No. 1-4, pp. 23-59.

Ikodinović, O. (2019, October 25). Srbija od Rusije kupuje oružje za 600 miliona dolara [Serbia buys weapons from Russia for $\$ 600$ million]. Radio Sputnik, retrieved from https:/ /rs-lat.sputniknews.com/analize/ 201910251121075191-srbija-od-rusije-kupuje-oruzje-za-600-milionadolara-/. Accessed 11 January 2020.

Institute for European Affairs. (2019). Šta građani Srbije misle o Rusiji? [What do the citizens of Serbia think about Russia?], Research No. 17. Institut for European Affairs, Belgrade.

Jovanović, M. (2012). Srbi i Rusi: 12-21. vek - istorija odnosa [Serbs and Russians: 12-21 ${ }^{\text {st }}$ century - the history of relationships]. Belgrade, Bookbridge.

Kjeza, Đ. (2016). Rusofobija [Russophobia]. Belgrade, Albatros plus.

Koncepciya vneshney politiki Rossiyskoy Federatsii [The concept of foreign policy of the Russian Federation], The Ministry of Foreign Affairs of the Russian Federation. (2013).

Koncepciya vneshney politiki Rossiyskoy Federatsii [The concept of foreign policy of the Russian Federation], The Ministry of Foreign Affairs of the Russian Federation. (2016).

Narodna skupština Republike Srbije [National Assembly of the Republic of Sebia]. (2019). Strategija nacionalne bezbednosti Republike Srbije [National Security Strategy of the Republic of Serbia], Belgrade.

Popularan u Srbiji: Putin ima selo, crkvu, rakiju... [Popular in Serbia: Putin has a village, a church, a schnapps ... ]. (2019, January 16), retrieved from https://www.novosti.rs/vesti/naslovna/drustvo/aktuelno.290.html:7 71844-POPULARAN-U-SRBIJI-Putin-ima-selo-crkvu-rakijuVIDEO. Accessed 1 January 2020.

Proroković, D. (2012). Geopolitika Srbije: položaj i perspektive na početku XXI veka [Geopolitics of Serbia: Position and Perspectives at the Beginning of the 21st Century]. Belgrade, Službeni glasnik.

Proroković, D. (2013). Kosovo: medzietnické a politické vztahy [Kosovo: interethnical and political relations]. Bratislava, Spolok Sr. na Slovensku. 
Proroković, D. (2015). The Geography of the Balkans in reference to the Energetics of Continental Europe: one route for several gas pipeline projects, in: Gas Geopolitics in South East Europe (pp. 11-23). Sofia, Bulgarian Geopolitical Society, The Institute for Balkan and European Studies.

Proroković, D. (2018). Era multipolarnosti [The era of multipolarity]. Belgrade, Službeni glasnik.

Proroković, D. (Ed.). (2018). Kosovo: sui generis or precedent in international relations. Belgrade, Institute of International Politics and Economics.

Radojević, M. (2014). Srpsko - ruski odnosi (1914-1990) [Serbian - Russian relationship (1914-1990)], in: Dragomir Anđelković (Ed.), Ruski nekropolj u Beogradu: Znamenje istorijskog prijateljstva [Russian necropolis in Belgrade: Sign of historical friendship] (pp. 46 - 63). Belgrade, Institute for political and economic dialogue.

Ruski general: Srbija je pod ruskom zaštitom [Russian army general: Serbia is under Russian protection]. (2019, October 25), retrieved from https://rs.sputniknews.com/rusija/201910251121076168-ruski-generalu-okruzenju-baza-natosrbiji-je-potrebna-stalna-zastita/. Accessed 11 January 2020.

Ruski kredit za železnicu [Russian loan for railway]. (2013, January 1), retrieved from http:// www.rts.rs/page/stories/sr/story/13/ekonomija /1245354/ruski-kredit-za-zeleznicu.html. Accessed 1 January 2020.

Više mladih Srba protiv ulaska u EU, a za savezništvo sa Rusijom [More young Serbs against joining the EU, and for an alliance with Russia]. (2019, August 15), retrieved from http://rtv.rs/sr_lat/mladi/aktuelno/ vise-mladih-srba-protiv-ulaska-u-eu-a-za-saveznistvo-sarusijom_1040711.html. Accessed 13 January 2020.

Vlahović, B. (2014). Putin - moć Rusije [Putin - the power of Russia]. Belgrade, Vukotić media Press. 